Wang, J; Yadav, V; Smart, AL; Tajiri, S; Basit, AW; (2015) Toward oral delivery of biopharmaceuticals: an assessment of the gastrointestinal stability of 17 peptide drugs. Mol Pharm , 12 (3) 966 - 973. 10.1021/mp500809f.

Article

\title{
Toward Oral Delivery of Biopharmaceuticals: An Assessment of the Gastrointestinal Stability of 17 Peptide Drugs
}

Jie Wang, Vipul Yadav, Alice Parry, Shinichiro Tajiri ${ }^{1}$, Abdul W. Basit*

Department of Pharmaceutics, UCL School of Pharmacy, University College London, WC1N 1AX, London, UK

*Corresponding author. Tel.: +44 207753 5865; fax: +44 2077535865.

E-mail addresses: a.basit@ucl.ac.uk (A.W. Basit).

${ }^{1}$ Present address: Formulation Technology Research Laboratories, Daiichi Sankyo Co., Ltd., Tokyo, Japan. 


\begin{abstract}
A major barrier to successful oral delivery of peptide and protein molecules is their inherent instability in the lumen of the gastrointestinal tract. The aim of this study was to determine the stability of 17 disparate peptide drugs (insulin, calcitonin, glucagon, secretin, somatostatin, desmopressin, oxytocin, $\left[\mathrm{Arg}^{8}\right]$ - vasopressin, octreotide, ciclosporin, leuprolide, nafarelin, buserelin, histrelin, [D-Ser] ${ }^{4}$ - gonadorelin, deslorelin, goserelin) in gastric and small intestinal fluids from both humans and pigs, and in simulated gastric and intestinal fluids. In human gastric fluid, the larger peptides including somatostatin, calcitonin, secretin, glucagon and insulin were metabolized rapidly, whereas the smaller peptides showed good stability. In human small intestinal fluid, however, both small and large peptides degraded rapidly with the exception of the cyclic peptide ciclosporin and the disulfide-bridge containing peptides octreotide and desmopressin, which showed good stability. From the investigations in simulated gastric and intestinal fluids without their respective enzymes pepsin and pancreatin, it was established that the $\mathrm{pH}$ was not responsible for peptide degradation. The stability of peptides in both simulated gastric fluid and pig gastric fluid correlated well with stability in human gastric fluid. However it was not possible to establish such a correlation with the small intestinal fluids because of the rapid rate of peptide degradation. This work has identified the molecular features in the structure of a wide range of peptides that influence their stability in the environment of the gastrointestinal tract, which in turn will allow for better selection of peptide candidates for oral delivery.
\end{abstract}

\title{
KEYWORDS
}

Biopharmaceuticals, peptides and proteins; metabolism; simulated gastrointestinal fluids; pig gastrointestinal fluids; human gastrointestinal fluids.

\section{INTRODUCTION}

The increasingly widespread use of peptides and proteins as therapeutic drugs is rapidly expanding in diverse fields such as neurology, oncology, endocrinology, haematology, as well as in the treatment of inflammatory diseases. Coupled with recent advances in molecular biology and biotechnology, this has led to the synthesis of several peptide and protein molecules which offer the advantages of high activity, high specificity, low toxicity and minimal non-specific or drug-drug interactions. Somewhat inevitably, however, these drugs are also not without their shortcomings: The vast majority of currently marketed peptide drugs are delivered parenterally on account of stability issues; a route often unacceptable to the patient due to issues of pain and discomfort with administration, and which frequently leads to low patient compliance. Equally, there is also the associated issue of high systemic bioavailability and the risk of potentially severe side-effects with the intravenous route, including hypersensitivity responses. Various non-parenteral routes for the systemic delivery of peptide drugs have been so far investigated, including transdermal, nasal, buccal and pulmonary delivery, which have been met with some success in achieving therapeutic goals. ${ }^{1-4}$ The oral route is another increasingly-investigated alternative, given that it offers advantages in terms of ease of administration, lower manufacturing costs and increased patient compliance. To date, however, there are currently only five marketed orally delivered peptide and protein drugs available; desmopressin, ciclosporin, vancomycin, linaclotide and pancreatin. These molecules are orally 
available due to either the low systemic dose required (desmopressin), ${ }^{5}$ their high lipophilicity (ciclosporin), ${ }^{6}$ or because they are targeted for local, intestinal delivery (vancomycin, linaclotide and pancreatin). ${ }^{7,8}$

The two major barriers to effective oral peptide drug delivery include the instability of peptides in the gastrointestinal (Gl) tract, and erratic absorption across the intestinal membrane into the systemic circulation. In terms of luminal stability, the highly acidic condition of the stomach is believed to be responsible for degradation of peptide drugs through destabilization of the threedimensional structural folding by interference with ionic and hydrogen bonding. ${ }^{9}$ Moreover the gastric-secreted enzyme pepsin and the intestinally-secreted enzymes trypsin, chymotrypsin, elastase and brush-border membrane-bound enzymes carboxypeptidases $A$ and B cause hydrolysis of specific bonds, leading to peptide degradation and loss of structure and activity. ${ }^{9,10}$

The stability of peptides with Gl enzymes and fluids have been assessed previously, but these studies have typically involved investigating only 1 or 2 peptide drugs, making it difficult to compare across studies due to variations in experimental conditions, biological fluids and analytical techniques. For instance, studies have included desmopressin stability in the presence of gastrointestinal enzymes, ${ }^{11}$ oxytocin and Arg-vasopressin in human stomach and small intestinal fluids, ${ }^{12}$ and insulin in pig gastric and intestinal luminal fluids. ${ }^{13}$ It would be of use, therefore, to assess the intestinal stability of a wider range of peptide drugs using the same biological fluids and analytical techniques within the same study in order to allow accurate comparisons to be made. This would enable the identification of those structural features that influence gastric and intestinal stability, allow for better selection of oral delivery candidates, and determine suitable formulation strategies.

The aim of this study was to evaluate the stability of 17 disparate peptide drugs in human gastric (HGF) and small intestinal fluids (HIF), pig gastric (PGF) and small intestinal fluids (PIF) and simulated gastric (SGF) and intestinal fluids (SIF). The drugs display different physical and chemical properties and were selected to understand structural influences on gastric and intestinal stability. A schematic representation of the peptides along with their physicochemical properties is shown in Table 1. The molecules can be separated into three groups; a) small peptides with fewer than 12 amino acids and a partial or complete cyclic structure (desmopressin, oxytocin, Arg-vasopressin, octreotide and ciclosporin), b) small and linear peptides with fewer than 12 amino acids (nafarelin, buserelin, goserelin, histrelin, leuprolide, [DSer] ${ }^{4}$-Gonadorelin and deslorelin) and c) large peptides with more than 12 amino acids (somatostatin, calcitonin, glucagon, secretin and insulin). This is the first study to comprehensively evaluate the gastrointestinal stability of a large number of peptides, and the data from the study will be useful in the selection of peptide candidate for oral peptide delivery. 
Table 1 Physical properties of peptide molecules calculated by ChemSpider using the ACD/PhysChem Suite and software ChemAxon or unless referenced otherwise

\begin{tabular}{|c|c|c|c|c|c|c|c|c|}
\hline Peptides & $\begin{array}{l}\text { Molecular } \\
\text { weight }\end{array}$ & $\begin{array}{l}\text { No. of } \\
\text { amino } \\
\text { acids }\end{array}$ & $\begin{array}{l}\text { Isoelectric } \\
\text { point }\end{array}$ & $\log P$ & $\begin{array}{l}\text { No. of } \mathrm{H} \text { bond } \\
\text { acceptors }\end{array}$ & $\begin{array}{l}\text { No. of } \mathbf{H} \\
\text { bond } \\
\text { donors }\end{array}$ & $\begin{array}{l}\text { No. of Freely } \\
\text { rotating } \\
\text { bonds }\end{array}$ & $\begin{array}{c}\text { Polar Surface } \\
\text { area }\end{array}$ \\
\hline Ciclosporin & 1202.6 & 11 & 4.70 & 3.64 & 23 & 5 & 16 & 278.80 \\
\hline Oxytocin & 1007 & 9 & 8.57 & -5.00 & 24 & 16 & 19 & 399.53 \\
\hline Desmopressin & 1128.3 & 9 & 10.22 & -6.13 & 26 & 18 & 20 & 435.41 \\
\hline Octreotide & 1019.2 & 8 & 10.97 & -1.69 & 20 & 15 & 22 & 329.32 \\
\hline \multicolumn{9}{|l|}{ Small Linear Peptides } \\
\hline$[\mathrm{D}-\mathrm{Ser}]^{4}$ Gonadorelin & 1182.2 & 10 & 10.19 & -6.26 & 30 & 19 & 33 & 471.73 \\
\hline Buserelin & 1299.4 & 9 & 10.17 & -3.35 & 29 & 17 & 35 & 437.87 \\
\hline Leuprolide & 1209.4 & 9 & 10.07 & -2.75 & 28 & 17 & 34 & 428.64 \\
\hline Goserelin & 1269.4 & 10 & 9.72 & -5.11 & 32 & 20 & 35 & 492.99 \\
\hline Deslorelin & 1282.4 & 9 & 9.96 & -2.44 & 29 & 18 & 34 & 439.03 \\
\hline \multicolumn{9}{|l|}{ Large peptides } \\
\hline Somatostatin & 1638.1 & 14 & 10.20 & -8.50 & 37 & 26 & 32 & 610.33 \\
\hline Calcitonin & 3432 & 32 & 10.14 & -28.49 & 54 & 52 & 98 & 1508.91 \\
\hline
\end{tabular}




$\begin{array}{ccccccccc}\text { Glucagon } & 3485 & 29 & 8.20 & -26.70 & 92 & 63 & 124 & 1580.71 \\ \text { Secretin } & 3039 & 36 & 10.68 & -24.89 & 47 & 52 & 109 & 1401.22 \\ \text { Insulin } & 5809 & 51 & 5.40^{14} & - & 88 & 89 & 166 & 2450\end{array}$




\section{MATERIALS AND METHODS}

\section{Materials}

Oxytocin acetate, buserelin acetate, goserelin acetate, nafarelin acetate, desmopressin acetate, leuprolide acetate, histrelin, [D-Ser] -Gonadorelin, human recombinant insulin and $\left[\mathrm{Arg}^{8}\right.$ ]vasopressin acetate were obtained from Sigma-Aldrich, UK. Octreotide, deslorelin, somatostatin, glucagon, secretin and salmon calcitonin were purchased from Oxford Expression Technologies, UK. Ciclosporin was sourced from Abcam plc, UK. Trifluoroacetic acid, tween 80, pepsin from porcine gastric mucosa, 469 units/mg solid, pancreatin from porcine pancreas, activity at least 3 times more than USP specifications were obtained from Sigma-Aldrich, UK. All other chemicals and solvents were of analytical reagent grade and used without further purification. All the salts were obtained from standard commercial sources.

\section{Sourcing and preparation of gastrointestinal fluids}

\section{Human gastric fluid (HGF) and human intestinal fluid (HIF)}

HGF and HIF were provided by AstraZeneca, Sweden, through the University of Uppsala, Sweden. The sampling of fluids from the stomach and upper jejunum was achieved using an intestinal intubation device via the Loc-I-Gut ${ }^{\circledR}$ procedure. $^{15,16}$ The $\mathrm{pH}$ of the HGF and HIF was 1.8 and 7.6 respectively.

\section{Pig gastric fluid (PGF) and pig intestinal fluid (PIF)}

Pig gastrointestinal tracts were obtained from three cross-breed of large white and landrace pigs (95-110 kg, 6 months old) at a meat factory (Cheale Meats, Essex, UK). The gastrointestinal tracts from pigs were then dissected to collect the fluid from the stomach and upper small intestine (duodenum and jejunum). The fluid was collected within 5 hours at $4^{\circ} \mathrm{C}$ after sacrifice of the pigs and immediately stored at $-80^{\circ} \mathrm{C}$. The fluid was centrifuged at $10,000 \mathrm{rpm}$ for 10 minutes, and the supernatants were used in the stability studies. The $\mathrm{pH}$ of the gastric and small intestinal supernatants was $3.4 \pm 0.4$ and $6.6 \pm 0.2$ respectively.

\section{Simulated gastric fluid (SGF) and simulated intestinal fluid (SIF)}

SGF was prepared according to USP specifications (Test Solutions, United States Pharmacopeia 35, NF 30, 2012). $0.2 \mathrm{~g}$ of sodium chloride was added to a $100 \mathrm{ml}$ flask and dissolved in $50 \mathrm{ml}$ water. $0.7 \mathrm{ml}$ of $10 \mathrm{M} \mathrm{HCl}$ was added to adjust the $\mathrm{pH}$ of the solution to 1.2 . To this, $0.32 \mathrm{~g}$ of pepsin was added and dissolved with gentle shaking, and the volume made up to $100 \mathrm{ml}$ with water. Pepsin was added only after the $\mathrm{pH}$ was adjusted to 1.2. SIF was prepared according to USP specifications (Test Solutions, United States Pharmacopeia 35, NF $30,2012) .0 .68 \mathrm{~g}$ of monobasic potassium phosphate was dissolved in $25 \mathrm{ml}$ water, then $7.7 \mathrm{ml}$ of $0.2 \mathrm{~N} \mathrm{NaOH}$ was added to adjust the $\mathrm{pH}$ to 6.8 . To this, $1 \mathrm{~g}$ of pancreatin was added and shaken gently until dissolved, and the volume adjusted to $100 \mathrm{ml}$ with water. Pancreatin was added after adjusting the $\mathrm{pH}$ of the solution to 6.8 to avoid precipitation of the enzyme. 


\section{Determination of protease activity of the small intestinal fluids}

A protease activity kit (Sigma Aldrich, USA) was used to investigate the protease activity of HIF, PIF and SIF. The protease activity kit contained casein labelled with fluorescein isothiocyanate (FITC) as the substrate, with an excitation/emission maxima of 485/520 nm. $20 \mu$ of incubation buffer, $20 \mu \mathrm{l}$ of FITC-casein substrate and $10 \mu \mathrm{l}$ of test sample (SIF with pancreatin/PIF/HIF) were added to an eppendorf tube and incubated at $37^{\circ} \mathrm{C}$ for 2 hours. After incubation, $150 \mu l$ of trichloroacetic acid (TCA) was added to the solution. This was centrifuged, and the fluorescence of the supernatant was measured using a fluorometer (BMG LABTECH PheraStar, Germany). The protease activity was calculated using MARS data analysis software. One unit of activity was defined as the amount of protease needed to hydrolyze FITC casein to produce a fluorescence intensity equivalent to 1 ng of trypsin hydrolyzed FITC-Casein per hour at $37^{\circ} \mathrm{C}$.

\section{Peptide stability studies}

A stock solution of glucagon was prepared in $0.01 \mathrm{~N} \mathrm{HCl}$, while secretin and calcitonin were prepared in a $0.9 \% \mathrm{NaCl}$ solution to obtain a concentration of $6.7 \times 10^{-4} \mathrm{mM}$. Insulin stock solution was prepared in $0.001 \mathrm{~N} \mathrm{HCl}$ at a concentration of $3.4 \times 10^{-4} \mathrm{mM}$. All other peptide drugs were prepared by dissolving the drug in $0.9 \% \mathrm{NaCl}$ solution to obtain a concentration of $6.7 \mathrm{x}$ $10^{-4} \mathrm{mM}$.

The peptide incubation studies were performed in a Gallenkamp ${ }^{\circledR}$ shaking incubator at $37^{0} \mathrm{C}$ and $100 \mathrm{rpm}$ for 120 minutes. Peptide drug stock solution $\left(6.7 \times 10^{-4} \mathrm{mM}\right)$ was added to the Gl fluids and the final concentration of each peptide drug, with the exception of insulin, was $3.4 \times 10^{-5}$ $\mathrm{mM}$. For insulin, the stock solution $\left(3.4 \times 10^{-4} \mathrm{mM}\right)$ was added to Gl fluids to obtain a final concentration of $6.9 \times 10^{-5} \mathrm{mM}$ during incubation. The higher concentration of insulin was required due to the low limit of detection of insulin by high performance liquid chromatography (HPLC). All incubations were done in triplicates expect for the study in human fluids, which were done in duplicates.

Samples $(150 \mu \mathrm{l})$ were withdrawn at frequent time intervals and added to ice-cold stop reagent $(450 \mu l)$, i.e. methanol for gastric fluids and $0.1 \mathrm{~N} \mathrm{HCl}$ for intestinal fluids, to inactivate the enzymes and allow quantitative determination of intact peptide remaining. For insulin, the sample was added to $0.002 \mathrm{M} \mathrm{NaOH}$ and $0.01 \mathrm{~N} \mathrm{HCl}$ to inactivate the gastric and intestinal enzymes respectively. Initial experiments had confirmed that the stop reagent had no degradative effect on peptide drug stability. All the samples were centrifuged at 10,000 rpm $(9600 \mathrm{~g})$ for 10 minutes, and the supernatant was analysed quantitatively by HPLC.

Chromatographic analysis was performed with a HPLC system (Agilent Technologies, 1260 Infinity) equipped with pump (model G1311C), autosampler (model G1329B) and a diode-array UV detector (model G1314B). The different chromatographic parameters for the peptides are shown in Table 2. The calibration curves were linear in the range $1.7 \times 10^{-6} \mathrm{mM}$ to $3.4 \times 10^{-5} \mathrm{mM}$ for all peptides. The peptide peak could be separated from the peaks from degradation product and protein peaks from gastric and intestinal fluids. 
Table 2 HPLC parameters for quantitative analysis of peptide drugs

\begin{tabular}{|c|c|c|c|c|c|c|c|c|c|c|c|c|c|}
\hline & Somatostatin & \multicolumn{3}{|c|}{ Glucagon } & \multicolumn{3}{|c|}{ Calcitonin } & Secretin & Oxytocin & Buserelin & Desmopressin & Goserelin & Nafarelin \\
\hline \multirow[t]{3}{*}{ Column } & Luna $5 \mu \mathrm{C} 18$ & \multicolumn{3}{|c|}{ Luna $5 \mu \mathrm{C} 18$} & \multicolumn{3}{|c|}{ Luna $5 \mu \mathrm{C} 18$} & Luna $5 \mu \mathrm{C} 18$ & Luna $5 \mu \mathrm{C} 18$ & Luna $5 \mu \mathrm{C} 18$ & Luna $5 \mu \mathrm{C} 18$ & Luna $5 \mu \mathrm{C} 18$ & Luna $5 \mu \mathrm{C} 18$ \\
\hline & $150 \times 4.6 \mathrm{~mm}$ & \multicolumn{3}{|c|}{$150 \times 4.6 \mathrm{~mm}$} & \multicolumn{3}{|c|}{$150 \times 4.6 \mathrm{~mm}$} & $150 \times 4.6 \mathrm{~mm}$ & $150 \times 4.6 \mathrm{~mm}$ & $150 \times 4.6 \mathrm{~mm}$ & $150 \times 4.6 \mathrm{~mm}$ & $150 \times 4.6 \mathrm{~mm}$ & $150 \times 4.6 \mathrm{~mm}$ \\
\hline & Phenomenex ${ }^{\circledR}$ & \multicolumn{3}{|c|}{ Phenomenex ${ }^{\circledR}$} & \multicolumn{3}{|c|}{ Phenomenex ${ }^{\circledR}$} & Phenomenex ${ }^{\circledR}$ & Phenomenex ${ }^{\circledR}$ & Phenomenex ${ }^{\circledR}$ & Phenomenex ${ }^{\circledR}$ & Phenomenex ${ }^{\circledR}$ & Phenomenex $^{\circledR}$ \\
\hline Temperature & $40^{\circ} \mathrm{C}$ & \multicolumn{3}{|c|}{$25^{\circ} \mathrm{C}$} & \multicolumn{3}{|c|}{$25^{\circ} \mathrm{C}$} & $25^{\circ} \mathrm{C}$ & $25^{\circ} \mathrm{C}$ & $33^{\circ} \mathrm{C}$ & $25^{\circ} \mathrm{C}$ & $33^{\circ} \mathrm{C}$ & $25^{\circ} \mathrm{C}$ \\
\hline Injection & $50 \mu 1$ & \multicolumn{3}{|c|}{$50 \mu 1$} & \multicolumn{3}{|c|}{$50 \mu 1$} & $50 \mu 1$ & $50 \mu 1$ & $50 \mu 1$ & $50 \mu 1$ & $50 \mu 1$ & $50 \mu 1$ \\
\hline \multicolumn{14}{|l|}{ Volume } \\
\hline Flow rate & $1 \mathrm{ml} / \mathrm{min}$ & \multicolumn{3}{|c|}{$1 \mathrm{ml} / \mathrm{min}$} & \multicolumn{3}{|c|}{$1 \mathrm{ml} / \mathrm{min}$} & $1 \mathrm{ml} / \mathrm{min}$ & $1 \mathrm{ml} / \mathrm{min}$ & $1 \mathrm{ml} / \mathrm{min}$ & $0.7 \mathrm{ml} / \mathrm{min}$ & $1 \mathrm{ml} / \mathrm{min}$ & $1 \mathrm{ml} / \mathrm{min}$ \\
\hline UV absorbance & $214 \mathrm{~nm}$ & \multicolumn{3}{|c|}{$220 \mathrm{~nm}$} & \multicolumn{3}{|c|}{$220 \mathrm{~nm}$} & $210 \mathrm{~nm}$ & $220 \mathrm{~nm}$ & $214 \mathrm{~nm}$ & $220 \mathrm{~nm}$ & $214 \mathrm{~nm}$ & $224 \mathrm{~nm}$ \\
\hline \multicolumn{14}{|l|}{$(\mathrm{nm})$} \\
\hline \multirow[t]{7}{*}{ Mobile Phase } & Acetonitrile & Time & $\mathrm{ACN}$ & Water & Time & $\mathrm{ACN}$ & Water & \multirow{4}{*}{$\begin{array}{c}\text { Acetonitrile : } \\
\text { Water : } 70 \% \\
\text { perchloric acid } \\
(37: 63: 0.5)\end{array}$} & \multirow{4}{*}{$\begin{array}{c}\text { Water } \\
(0.1 \% \mathrm{TFA}): \\
\text { Acetonitrile } \\
(83: 17)\end{array}$} & \multirow{4}{*}{$\begin{array}{c}\text { Water } \\
(0.1 \% \mathrm{TFA}): \\
\text { Acetonitrile } \\
(77: 23)\end{array}$} & \multirow{4}{*}{$\begin{array}{c}\text { Water } \\
(0.1 \% \text { TFA }): \\
\text { Acetonitrile } \\
(83: 17)\end{array}$} & \multirow{4}{*}{$\begin{array}{c}\text { Water } \\
(0.1 \% \text { TFA }): \\
\text { Acetonitrile } \\
(78: 22)\end{array}$} & \multirow{4}{*}{$\begin{array}{c}\text { Water } \\
(0.1 \% \text { TFA }): \\
\text { Acetonitrile } \\
(73: 27)\end{array}$} \\
\hline & $(\mathrm{ACN})$ : Water : & $(\min )$ & & $\%$ TFA) & $(\min )$ & $(0.1 \%$ & $\% \mathrm{TFA})$ & & & & & & \\
\hline & Phosphoric acid & 0 & $20 \%$ & $80 \%$ & 0 & $10 \%$ & $90 \%$ & & & & & & \\
\hline & $(22: 78: 0.5)$ & 6 & $39 \%$ & $61 \%$ & 6 & $37 \%$ & $63 \%$ & & & & & & \\
\hline & & 12 & $39 \%$ & $61 \%$ & 12 & $37 \%$ & $63 \%$ & & & & & & \\
\hline & & 14 & $20 \%$ & $80 \%$ & 14 & $10 \%$ & $90 \%$ & & & & & & \\
\hline & & 18 & $20 \%$ & $80 \%$ & 18 & $10 \%$ & $90 \%$ & & & & & & \\
\hline
\end{tabular}




\begin{tabular}{|c|c|c|c|c|c|c|c|c|}
\hline & Histrelin & Leuprolide & $\begin{array}{c}{[\mathrm{D}-\mathrm{Ser}]^{4}-} \\
\text { Gonadorelin }\end{array}$ & $\begin{array}{c}{\left[\operatorname{Arg}^{8}\right]-} \\
\text { vasopressin }\end{array}$ & Octreotide & Deslorelin & Ciclosporin & Insulin \\
\hline \multirow{2}{*}{ Column } & $150 \times 4.6 \mathrm{~mm}$ & $150 \times 4.6 \mathrm{~mm}$ & $150 \times 4.6 \mathrm{~mm}$ & $150 \times 4.6 \mathrm{~mm}$ & $150 \times 4.6 \mathrm{~mm}$ & $150 \times 4.6 \mathrm{~mm}$ & $150 \times 4.6 \mathrm{~mm}$ & $\begin{array}{r}300^{\circ} \mathrm{A} \mathrm{C} 18 \\
150 \times 4.6 \mathrm{~mm}\end{array}$ \\
\hline & Phenomenex ${ }^{\circledR}$ & Phenomenex $^{\circledR}$ & Phenomenex ${ }^{\circledR}$ & Phenomenex $^{\circledR}$ & Phenomenex ${ }^{\circledR}$ & Phenomenex ${ }^{\circledR}$ & Phenomenex ${ }^{\circledR}$ & \\
\hline Temperature & $25^{\circ} \mathrm{C}$ & $25^{\circ} \mathrm{C}$ & $25^{\circ} \mathrm{C}$ & $25^{\circ} \mathrm{C}$ & $25^{\circ} \mathrm{C}$ & $25^{\circ} \mathrm{C}$ & $70^{\circ} \mathrm{C}$ & $40^{\circ} \mathrm{C}$ \\
\hline Injection Volume & $50 \mu 1$ & $50 \mu 1$ & $50 \mu 1$ & $50 \mu 1$ & $50 \mu 1$ & $50 \mu 1$ & $50 \mu 1$ & $20 \mu \mathrm{l}$ \\
\hline Flow rate & $1 \mathrm{ml} / \mathrm{min}$ & $0.6 \mathrm{ml} / \mathrm{min}$ & $1 \mathrm{ml} / \mathrm{min}$ & $1 \mathrm{ml} / \mathrm{min}$ & $1 \mathrm{ml} / \mathrm{min}$ & $1 \mathrm{ml} / \mathrm{min}$ & $0.7 \mathrm{ml} / \mathrm{min}$ & $1 \mathrm{ml} / \mathrm{min}$ \\
\hline UV absorbance (nm) & $210 \mathrm{~nm}$ & $210 \mathrm{~nm}$ & $214 \mathrm{~nm}$ & $214 \mathrm{~nm}$ & $220 \mathrm{~nm}$ & $210 \mathrm{~nm}$ & $210 \mathrm{~nm}$ & $210 \mathrm{~nm}$ \\
\hline \multirow[t]{4}{*}{ Mobile Phase } & Water & Water & Water (0.1\%TFA) & Water & Water & Water & Water $(0.1 \%$ TFA $)$ & Water \\
\hline & $(0.1 \% \mathrm{TFA}):$ & $(0.1 \%$ TFA $):$ & : Acetonitrile & (0.1\%TFA) : & $(0.1 \%$ TFA) : & $(0.1 \%$ TFA $):$ & : Acetonitrile & (0.1\% TFA): \\
\hline & Acetonitrile & Acetonitrile & $(84: 16)$ & Acetonitrile & Acetonitrile & Acetonitrile & $(80: 20)$ & Acetonitrile \\
\hline & $(77: 23)$ & $(70: 30)$ & & $(87: 13)$ & $(82: 18)$ & $(75: 25)$ & & $(30-60 \%)$ \\
\hline
\end{tabular}




\section{Data analysis}

All experiments were performed in the same batch of Gl fluids to avoid inter-day variability, and the results are presented as mean \pm standard deviation (SD). The half-life $\left(t_{1 / 2}\right)$ of peptides in Gl fluids was calculated from their degradation profiles, by linear regression analysis assuming zero-order or first order degradation kinetics, using Origin 9 (OriginLab Corporation, MA, USA).

\section{RESULTS}

The stability of the peptides in human gastric fluid (HGF) is shown in Figure 1a. The stability of the peptides in pig gastric fluid (PGF) and simulated gastric fluid (SGF) with pepsin is shown in Figures $1 \mathrm{~b}$ and $1 \mathrm{c}$ respectively. With the exception of [D-Ser] ${ }^{4}$-Gonadorelin, the small peptides were stable in all three gastric fluids. In contrast, the large peptides were rapidly degraded within 10 minutes. Somatostatin was the exception as it showed relatively high stability in all gastric fluids.

The stability of the peptide drugs in human intestinal fluid (HIF) is shown in Figure $2 a$. The stability of the peptide drugs in PIF and SIF is shown in Figures $2 b$ and $2 c$ respectively. The large peptides as well as the small peptides buserelin, goserelin, deslorelin, histrelin and leuprolide degraded rapidly within 2-10 minutes in all three small intestinal fluids. The small peptides which did not follow this trend were nafarelin and [D-Ser] ${ }^{4}$-Gonadorelin which showed higher stability in PIF but rapid degradation HIF and SIF. Oxytocin showed uniform stability in all three small intestinal fluids, with complete degradation achieved after 30 minutes, while Argvasopressin was more stable in SIF than HIF and PIF. The peptides octreotide and desmopressin also showed relatively higher stability, but stability was variable between the fluids with fastest degradation observed in HIF followed by PIF and SIF. Ciclosporin was stable in all three small intestinal fluids.

Figure 1. Stability of peptide drugs in human gastric fluid (a), pig gastric fluid (b) and simulated gastric fluid with pepsin (c). Nafarelin $(\rightarrow)$, Buserelin $(-\bullet)$, Goserelin $(-\leftarrow)$, Histrelin $(*)$,

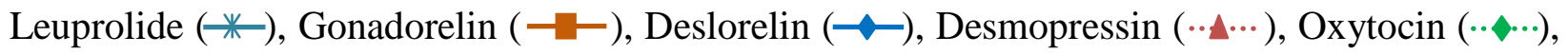

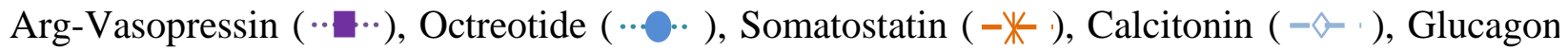
$(-\square)$, Secretin $\left(-\square^{-}\right)$, Insulin $\left(-\Theta^{\prime}\right)$, Ciclosporin $(\cdots * \cdots)$. 


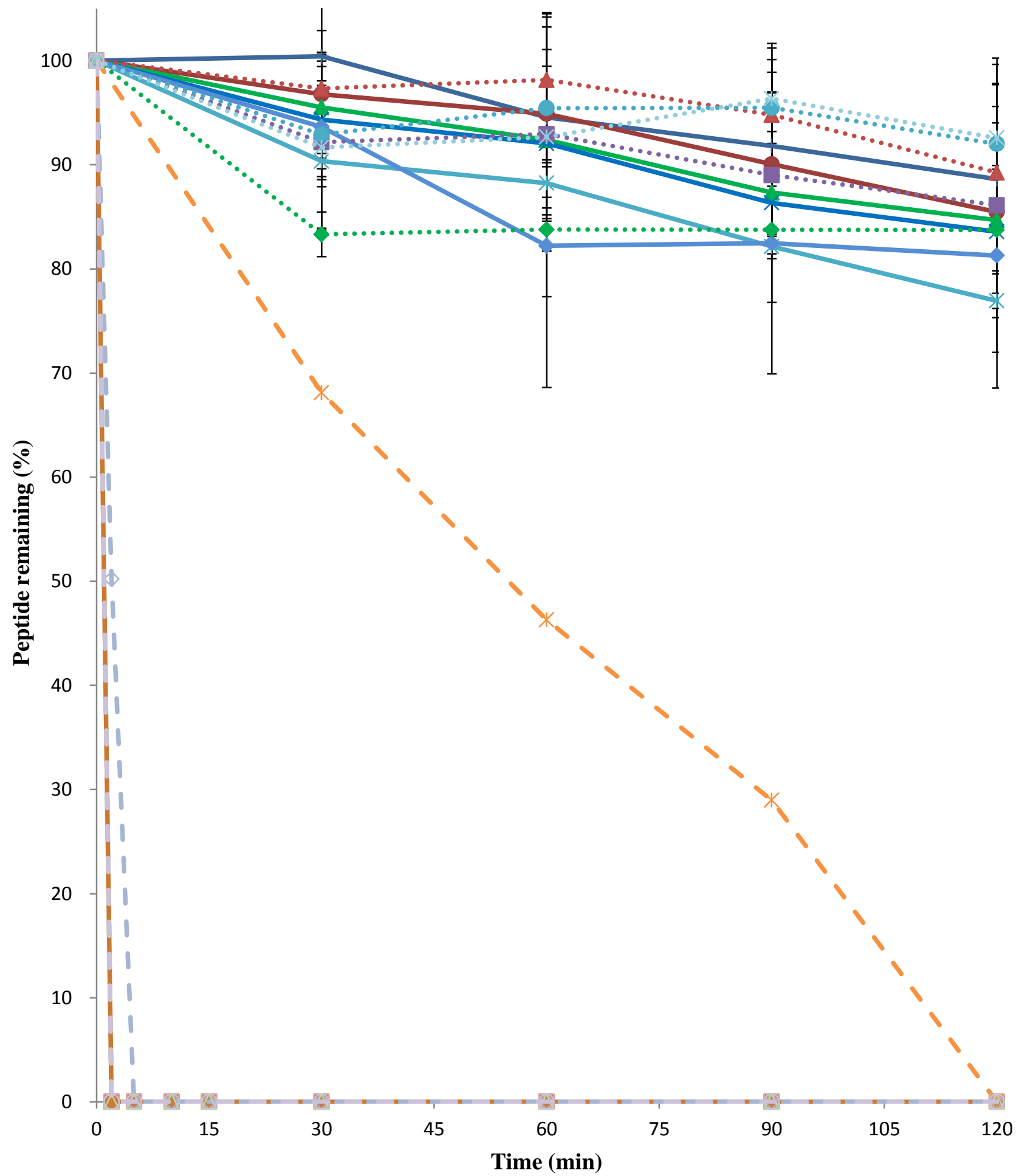

a) 


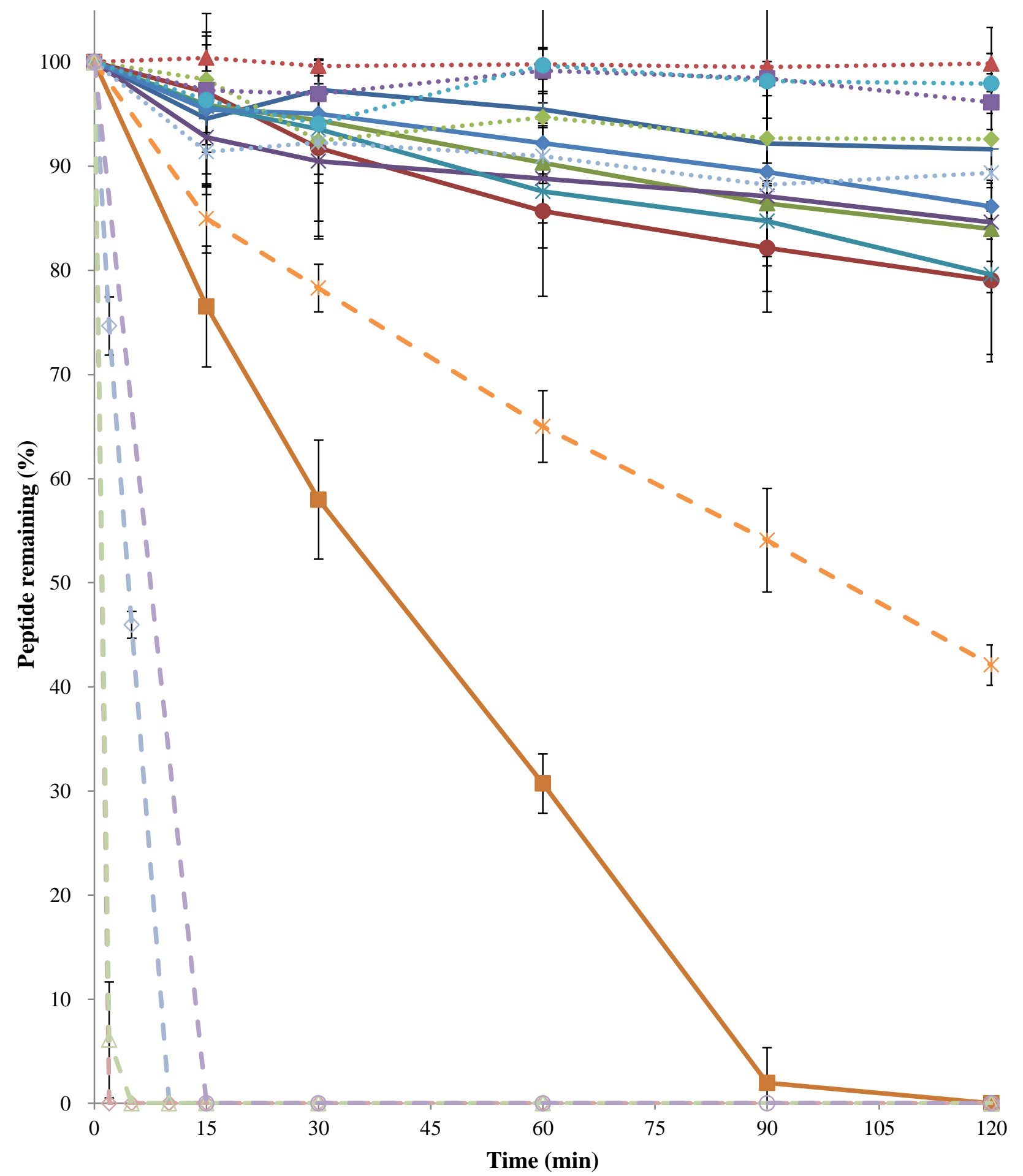

b) 


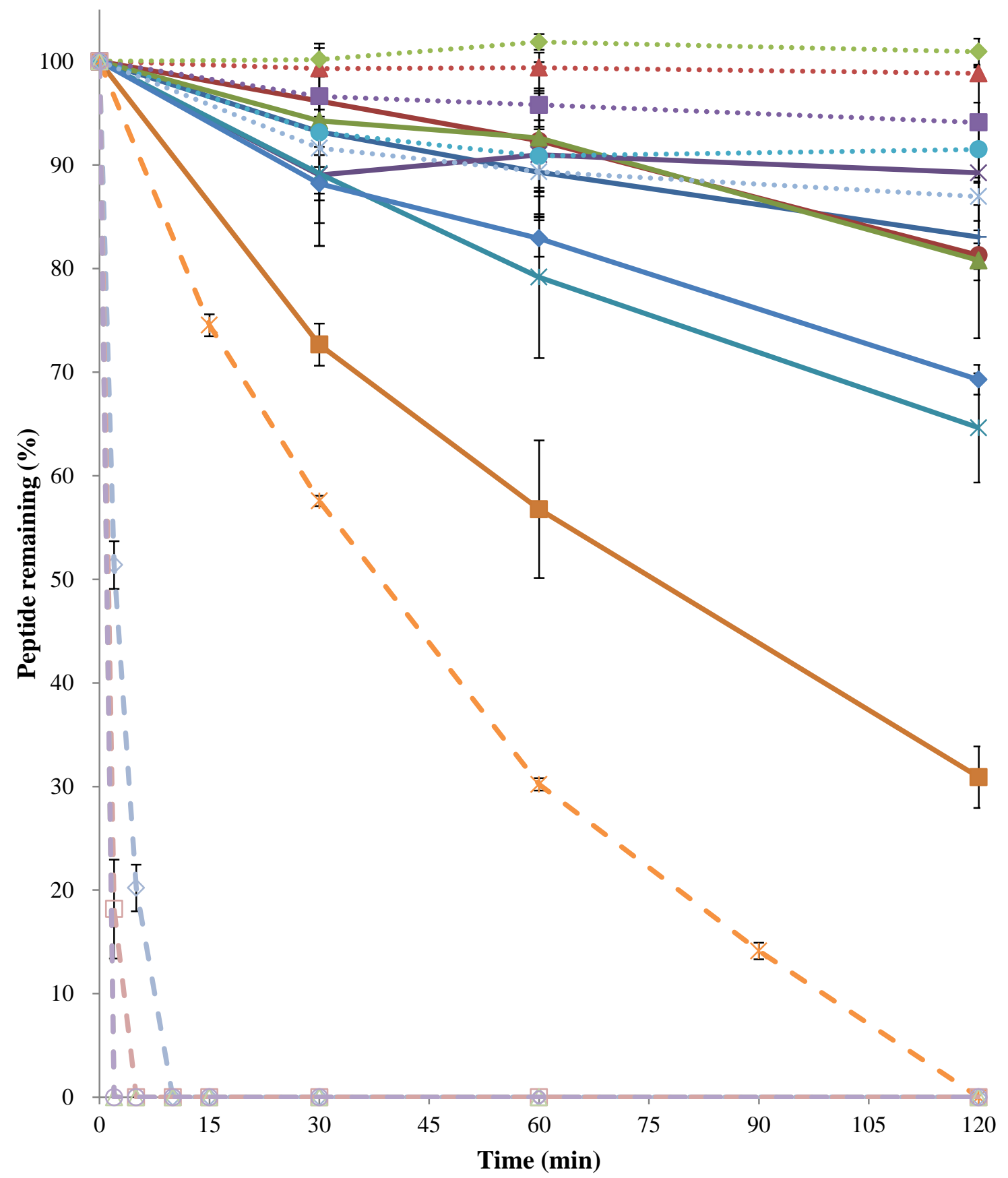

c) 
Figure 2. Stability of peptide drugs in human small intestinal fluid (a), pig intestinal fluid (b) and simulated intestinal fluid with pancreatin (c). Nafarelin $(+)$, Buserelin $(-\bullet)$, Goserelin $(--)$,

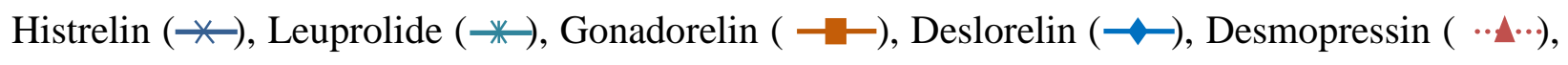
Oxytocin $(\cdots \bullet \cdot)$, Arg-Vasopressin $(\cdot \cdots \cdot \cdots)$, Octreotide $(\cdots \bullet \cdot)$, Somatostatin $(-*)$, Calcitonin $(-\diamond-)$, Glucagon $(-\square)$, Secretin $\left(-\triangle^{-}\right)$, Insulin $\left(-\odot^{\prime}\right)$, Ciclosporin $(\cdots * \cdots)$.

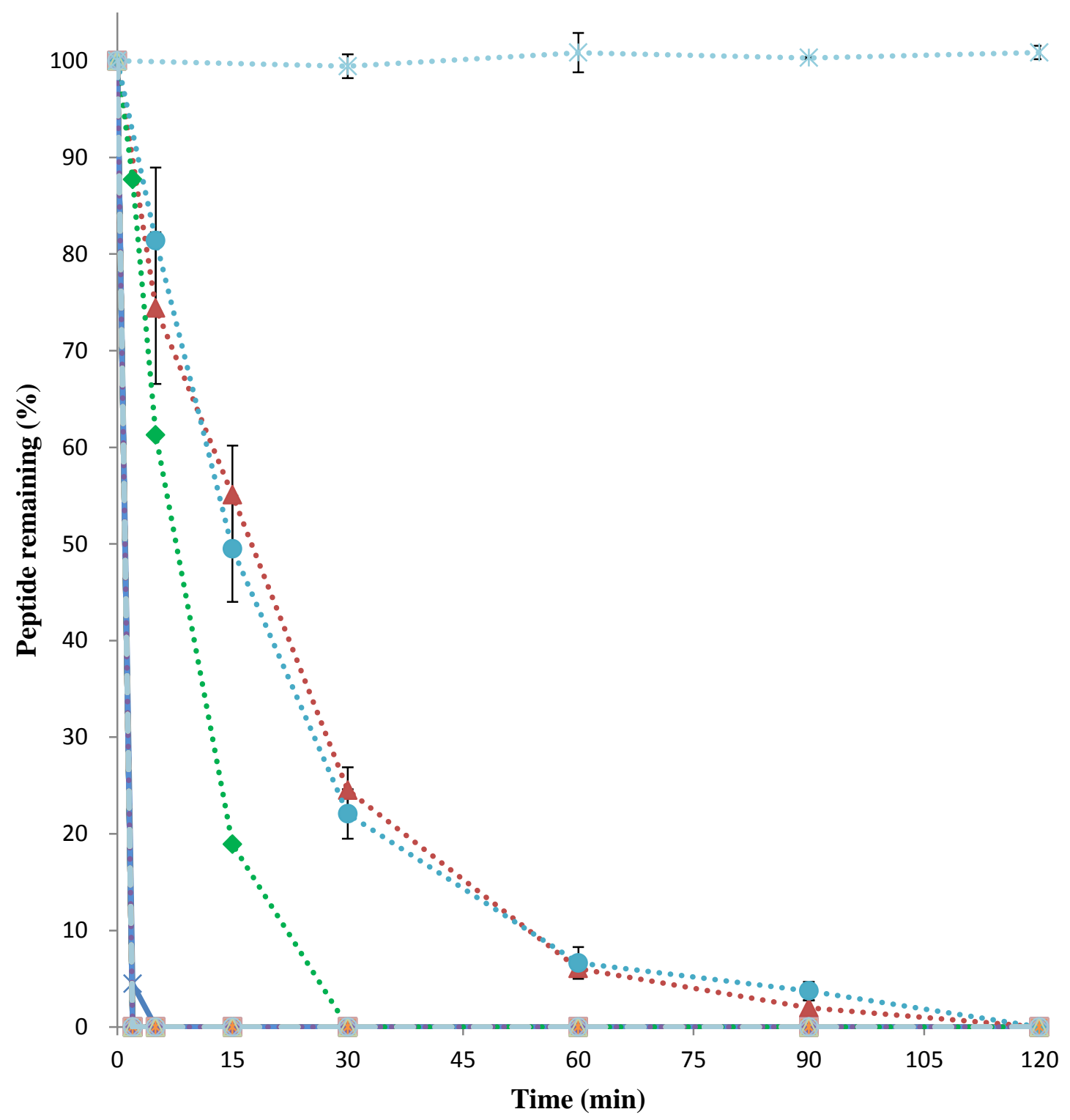

a) 


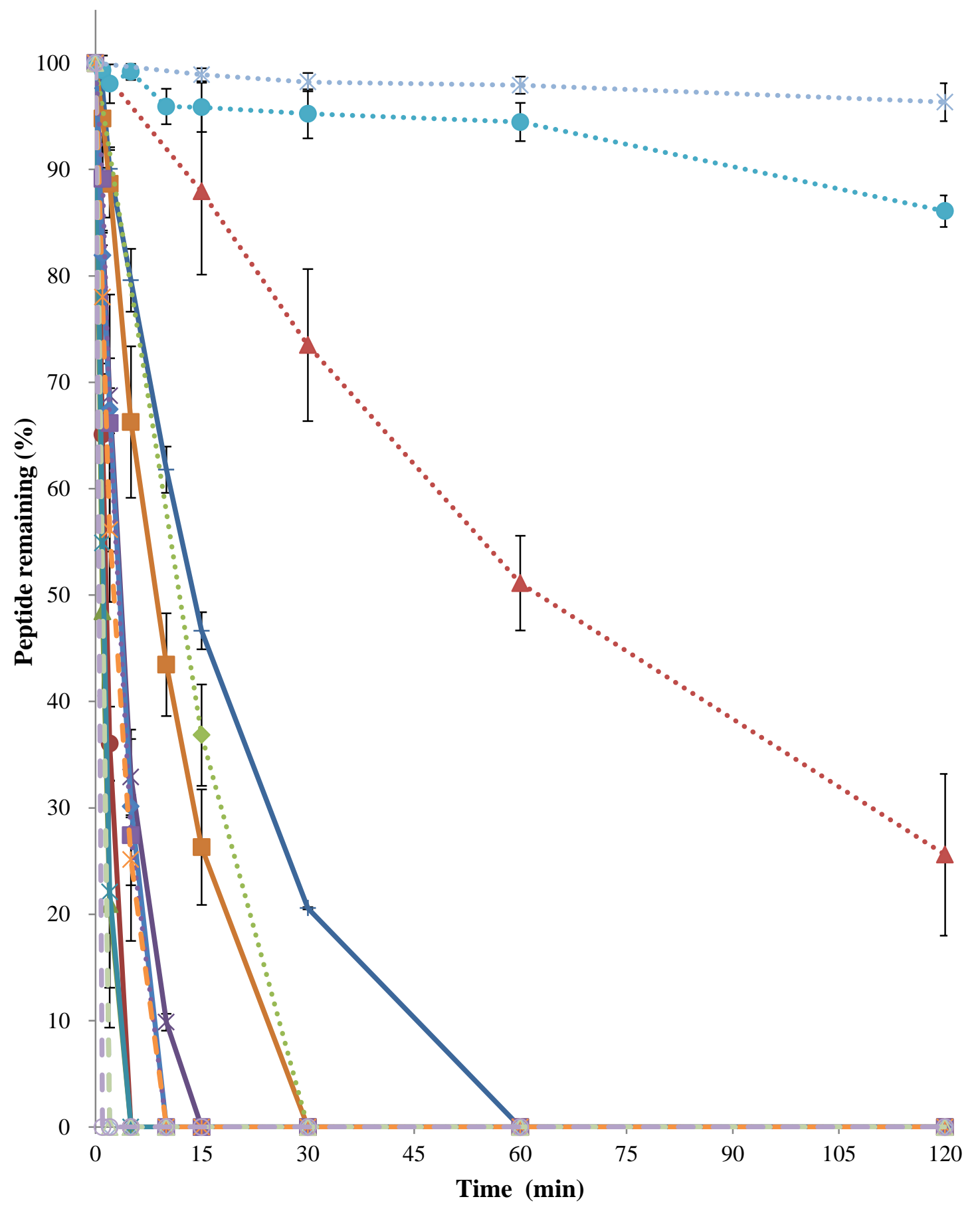

b) 


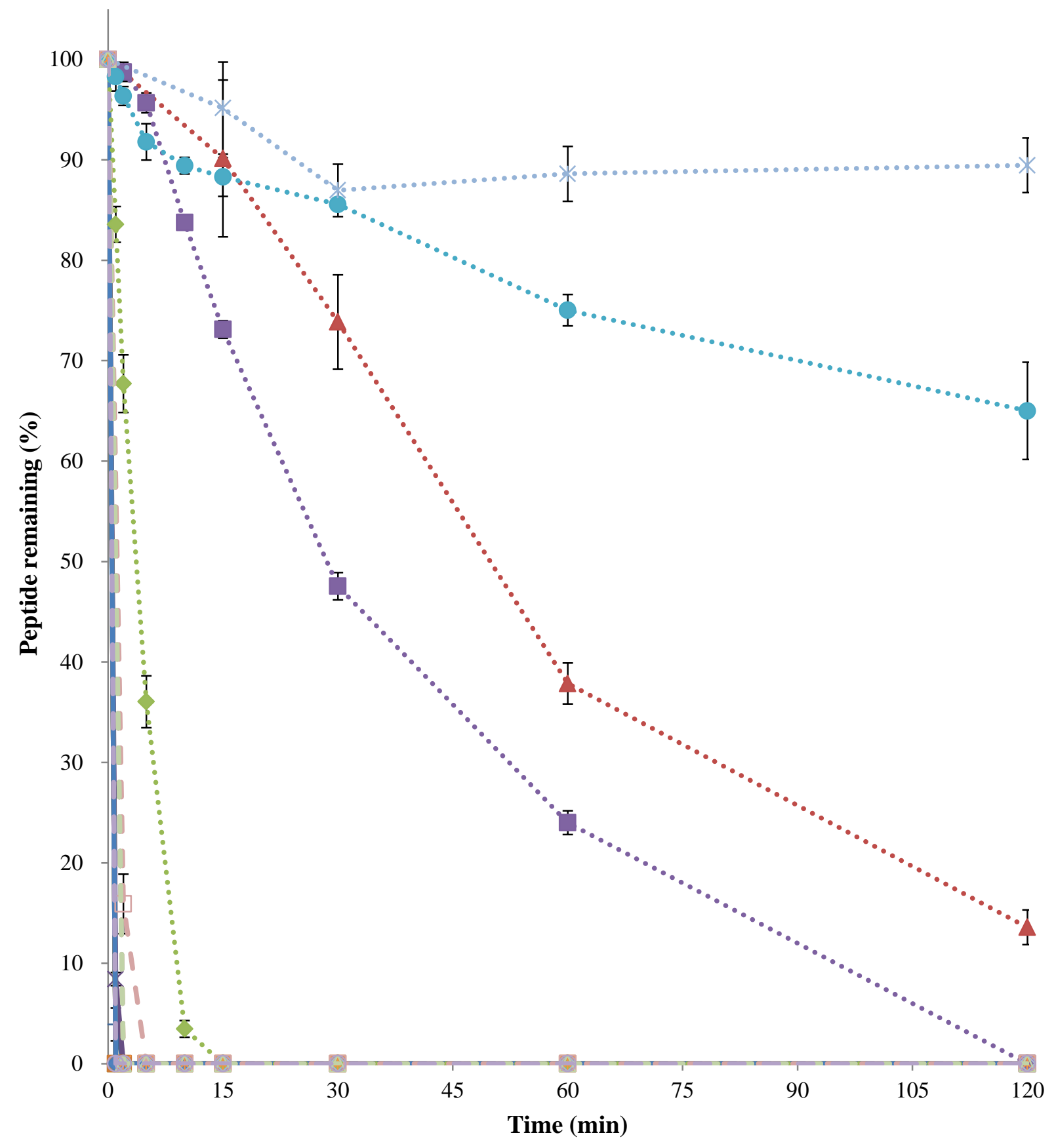

c) 
The stability of the peptides in SGF and SIF without their respective enzymes pepsin and pancreatin is shown in Figures 3 and 4 respectively. In both fluids, all peptides were stable with more than $80 \%$ drug recovery after 2 hours (with the exception of calcitonin in SIF without pancreatin), highlighting the dominant role of Gl enzymes in the breakdown and cleavage of the peptide structure.

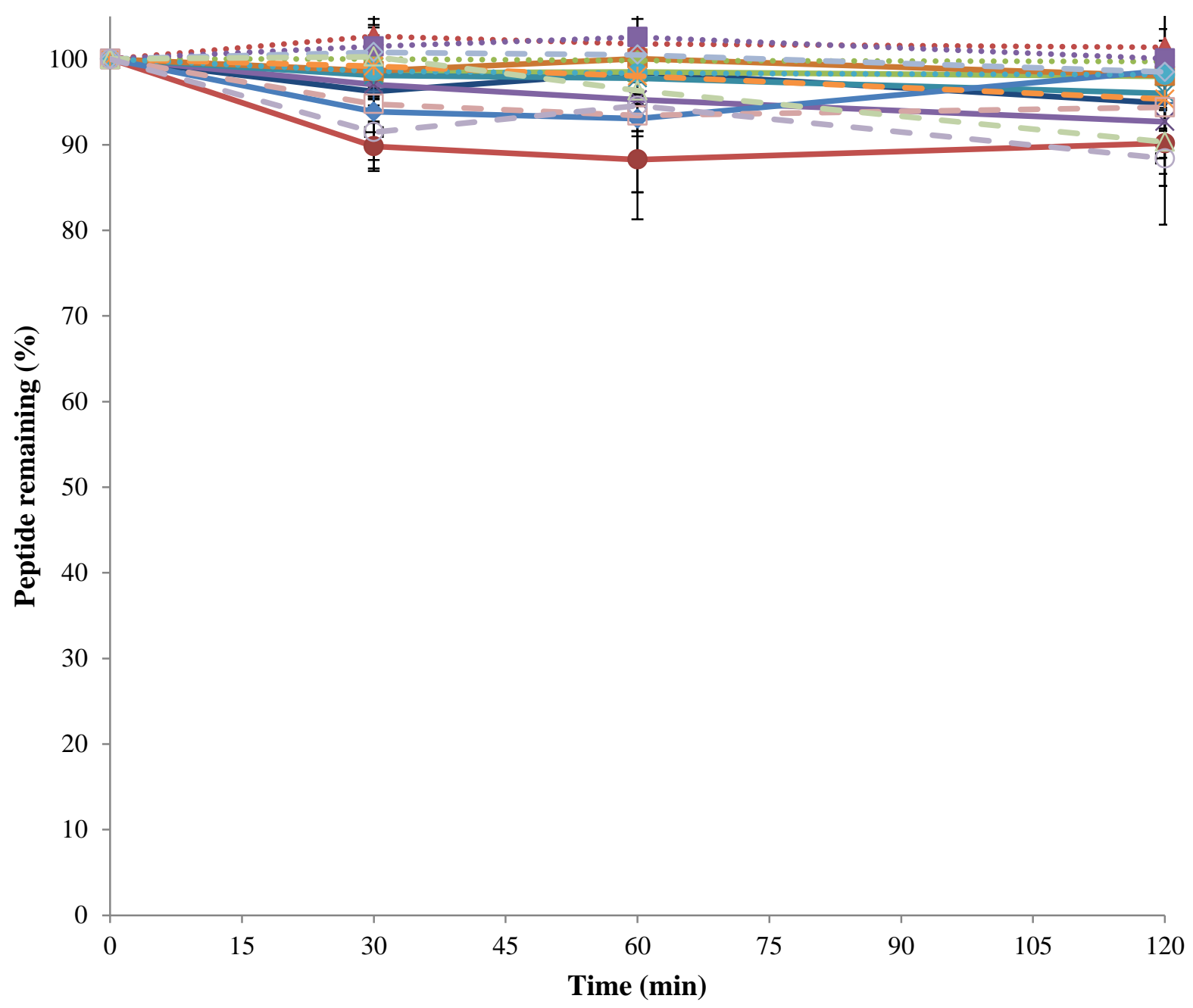

Figure 3. Stability of peptide drugs in intestinal fluid with pancreatin. Each value represents mean \pm S.D $(n=3)$. Nafarelin $(\leftarrow)$, Buserelin $(-<)$, Goserelin $(-\leftarrow)$, Histrelin $(*)$,

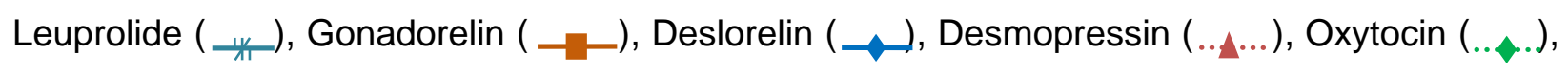

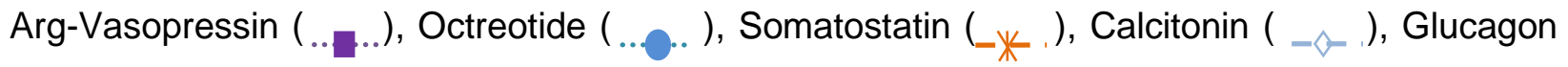
$\left({ }_{-\square}\right)$, Secretin $\left(\__{-\Delta_{-}}\right)$, Insulin $\left(_{-\odot}\right)$, Ciclosporin $\left(\ldots \ldots_{\ldots}\right)$. 


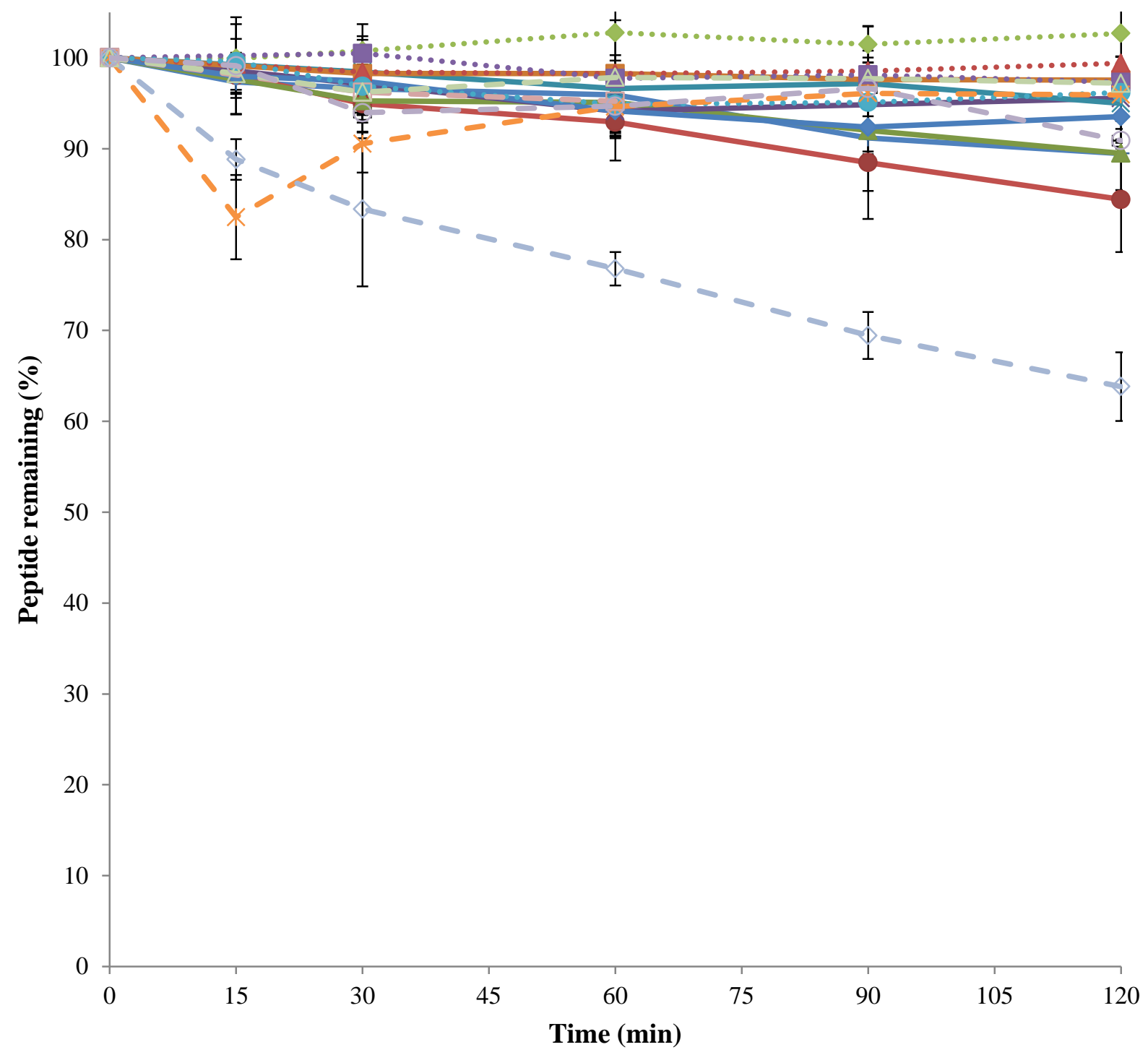

Figure 4. Stability of peptide drugs in simulated gastric fluid without pepsin enzyme. Each value represents mean \pm S.D $(\mathrm{n}=3)$. Nafarelin $(+)$, Buserelin $(-\bullet)$, Goserelin $(-\rightarrow)$, Histrelin $(-*)$, Leuprolide $\left({ }^{*}\right)$, Gonadorelin $(-\leftarrow)$, Deslorelin $(-\bullet)$, Desmopressin $(\cdots \cdots)$, Oxytocin $(\cdots \cdots)$,

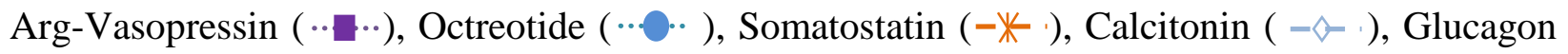
$(-\square)$, Secretin $\left(-\unlhd^{-}\right)$, Insulin $(-\odot \cdot)$. 
In order to further understand the role of protease enzymes in the degradation of peptides in gastric and small intestinal fluids, the protease activity of all these fluids was measured. The protease activity in SGF with pepsin, PGF and HGF was $14237 \pm 3099,6749 \pm 2464$ and 10072 \pm 3157 units $/ \mathrm{ml}$ respectively while the protease activity in SIF with pancreatin, PIF and HIF was $49649 \pm 2610,30730 \pm 5575,50608 \pm 3880$ units $/ \mathrm{ml}$ respectively. The half-lives of the peptide drugs in all three gastric and small intestinal fluids are shown in Table 2 and 3 respectively; the half-lives of large peptides could not be obtained due to rapid degradation within 2 minutes. Good correlations were observed for the stability of the peptides in SGF and HGF $\left(R^{2}=0.917\right)$, PGF and HGF $\left(R^{2}=0.932\right)$ and SGF and PGF $\left(R^{2}=0.917\right)$. This suggests the ability of SGF and PGF to be used as an in-vitro model to predict the stability of peptides in human stomach, as well as the usefulness of SGF to simulate pig gastric conditions.

\section{Table 2}

The half lives and \% peptide remaining after 2 hours in HGF, PGF and SGF with pepsin.

\begin{tabular}{ccc|cc|cc}
\hline Peptide & \multicolumn{2}{c|}{ HGF } & \multicolumn{2}{c}{ PGF } & \multicolumn{2}{c}{ SGF } \\
\cline { 2 - 7 } & $\begin{array}{c}\text { Half life } \\
\text { (mins) }\end{array}$ & $\begin{array}{c}\text { \% Drug } \\
\text { remaining } \\
\text { after 2 hours }\end{array}$ & $\begin{array}{c}\text { Half life } \\
\text { (mins) }\end{array}$ & $\begin{array}{c}\text { \% Drug } \\
\text { remaining } \\
\text { after 2 hours }\end{array}$ & $\begin{array}{c}\text { Half life } \\
\text { (mins) }\end{array}$ & $\begin{array}{c}\text { D Drug } \\
\text { remaining } \\
\text { after 2 hours }\end{array}$ \\
\hline Nafarelin & 491 & 89 & 822 & 92 & 357 & 83 \\
Buserelin & 424 & 85 & 274 & 79 & 324 & 81 \\
Goserelin & 385 & 85 & 376 & 84 & 322 & 81 \\
Histrelin & 363 & 84 & 440 & 85 & 661 & 89 \\
Leuprolide & 267 & 77 & 300 & 80 & 166 & 65 \\
[D-Ser]-Gonadorelin & $*$ & 0 & 46 & 0 & 80 & 31 \\
Deslorelin & 294 & 81 & 468 & 86 & 195 & 69 \\
Desmopressin & 633 & 89 & $\sim$ & 100 & $\sim$ & 99 \\
Oxytocin & 405 & 84 & 884 & 93 & $\sim$ & 100 \\
[Arg ${ }^{8}$ ]-vasopressin & 468 & 86 & $\sim$ & 96 & 1093 & 94 \\
Octreotide & 1071 & 92 & $\sim$ & 98 & 761 & 92 \\
Ciclosporin & 1374 & 93 & 667 & 89 & 480 & 87 \\
Somatostatin & 58 & 0 & 98 & 42 & 49 & 0 \\
Calcitonin & 2.0 & 0 & 4.6 & 0 & 2.1 & 0 \\
Glucagon & $*$ & 0 & $*$ & 0 & 1.2 & 0 \\
Secretin & $*$ & 0 & 1.1 & 0 & $*$ & 0 \\
Insulin & $*$ & 0 & $*$ & 0 & $*$ \\
\hline
\end{tabular}

$\sim$ Stable, $>95 \%$ peptide recovery after 2 hours

* Unable to calculate $t_{1 / 2}$ due to very fast degradation within 2 minutes 
Table 3

The half lives and \% peptide remaining after 30 minutes in HIF, PIF and SIF with pancreatin.

\begin{tabular}{ccc|cc|cc}
\hline Peptide & \multicolumn{2}{c|}{ HIF } & \multicolumn{2}{c|}{ PIF } & \multicolumn{2}{c}{ SIF } \\
\cline { 2 - 7 } & $\begin{array}{c}\text { Half life } \\
\text { (mins) }\end{array}$ & $\begin{array}{c}\% \text { Drug } \\
\text { remaining } \\
\text { after 30 mins }\end{array}$ & $\begin{array}{c}\text { Half life } \\
\text { (mins) }\end{array}$ & $\begin{array}{c}\% \text { Drug } \\
\text { remaining } \\
\text { after 30 mins }\end{array}$ & $\begin{array}{c}\text { Half life } \\
\text { (mins) }\end{array}$ & $\begin{array}{c}\% \text { Drug } \\
\text { remaining } \\
\text { after 30 mins }\end{array}$ \\
\hline Nafarelin & $*$ & 0 & 14 & 21 & 0.5 & 0 \\
Buserelin & $*$ & 0 & 1.4 & 0 & $*$ & 0 \\
Goserelin & $*$ & 0 & 0.9 & 0 & $*$ & 0 \\
Histrelin & 1.1 & 0 & 3.2 & 0 & $*$ & 0 \\
Leuprolide & $*$ & 0 & 1.0 & 0 & $*$ & 0 \\
[D-Ser] ${ }^{4}$-Gonadorelin & $*$ & 0 & 8.0 & 0 & $*$ & 0 \\
Deslorelin & $*$ & 0 & 2.9 & 0 & $*$ & 0 \\
Desmopressin & 15 & 25 & 63 & 73 & 50 & 74 \\
Oxytocin & 6.8 & 0 & 8.9 & 0 & 3.2 & 0 \\
[Arg ${ }^{8}$-vasopressin & $*$ & 0 & 2.9 & 0 & 30 & 48 \\
Octreotide & 15 & 22 & 554 & 95 & 163 & 86 \\
Ciclosporin & $\sim$ & 99 & $\sim$ & 98 & 499 & 87 \\
Somatostatin & $*$ & 0 & 2.4 & 0 & $*$ & 0 \\
Calcitonin & $*$ & 0 & $*$ & 0 & $*$ & 0 \\
Glucagon & $*$ & 0 & $*$ & 0 & $*$ & 0 \\
Secretin & $*$ & 0 & $*$ & 0 & $*$ & 0 \\
Insulin & $*$ & 0 & $*$ & 0 & $*$ & 0 \\
\hline
\end{tabular}

$\sim$ Stable, $>95 \%$ peptide recovery after 2 hours

* Unable to calculate $t_{1 / 2}$ due to very fast degradation within 2 minutes 


\section{DISCUSSION}

The high stability of peptides in SGF without pepsin and the degradation of peptides in SGF with pepsin established the negligible effect of $\mathrm{pH}$ and the importance of the enzyme in the degradation of peptides in gastric conditions. Pepsin specifically cleaves amino acids at L-Phe-, L-Met-, L-Leu-, and L-Trp, which are adjacent to a hydrophobic amino acid. ${ }^{17,18}$ Therefore the high gastric stability of the small peptides oxytocin, Arg-vasopressin, desmopressin, goserelin, buserelin, nafarelin and histrelin can be linked to the absence of pepsin-susceptible peptide bonds. Additionally, the peptides oxytocin, vasopressin and desmopressin feature disulfide bridges between their Cys amino acids which partially cyclizes their structure and results in high resistance to pepsin cleavage and their subsequent stability in gastric fluids. These results are in line with previous studies showing the high stability of Arg-vasopressin and desmopressin in gastric fluid. ${ }^{11,12}$ Interestingly, ciclosporin, octreotide, leuprolide and deslorelin which all contain pepsin-vulnerable peptide bonds were found to be stable in SGF with pepsin. However, the pepsin vulnerable amino acids at position 6 in leuprolide and deslorelin, and position 4 in octreotide, are in the D-confirmation which may render them more resistant to pepsin cleavage due to the enzyme's specificity towards L-amino acids. ${ }^{19}[\mathrm{D}-\mathrm{Ser}]^{4}$-Gonadorelin was degraded in gastric fluids even though it does not possess pepsin vulnerable bonds. This might be due to the L-confirmation of [D-Ser] ${ }^{4}$-Gonadorelin amino acid at position 6 compared to the Dconfirmation in other LHRH analogues. It was reported that the D-amino acid at position 6 could stabilize the U-shaped conformation of LHRH analogues, which could improve the binding affinity. ${ }^{20}$ Previous study has showed an analogue of gonadorelin with D-Lys amino acid substitution at position 6 to be stable in simulated gastric fluids with pepsin with $80 \%$ intact drug remaining after 2 hours. ${ }^{21}$ This may indicate the importance of D-confirmation of amino acid at position 6 for the stability of LHRH analogues in gastric fluids. The faster degradation of large peptides in gastric fluids may be due to multiple factors such as the presence of high number of pepsin susceptible peptide bonds, high structural flexibility and a greater number of $\mathrm{H}$ bond acceptors/donors, producing a higher polar surface area enabling increased interaction with $\operatorname{pepsin}^{8}$.

Pancreatin contains the proteases trypsin, chymotrypsin and elastase which are largely responsible for intestinal breakdown of peptide molecules. ${ }^{9}$ The peptide molecules were found to be degraded at different rates in small intestinal fluids, even though they all contain protease susceptible peptide bonds. This might be attributed to the differences in their physicochemical properties, as well as the different protease activity of the small intestinal fluids used in the current study. Indeed, the measured protease activity of SIF and HIF was almost 2-fold higher than for PIF, which may explain the higher stability of peptides such as octreotide, desmopressin and leuprolide in PIF. The greater stability of oxytocin, desmopressin, octreotide and ciclosporin as compared to the linear peptides in SIF could be attributed to their partial or complete cyclic structure and resultant reduced flexibility, fewer $\mathrm{H}$ bond acceptors/donors and fewer freely rotating, thereby restricting protease digestion. ${ }^{22,}{ }^{23}$ The superior stability of desmopressin over Arg-vasopressin may be due to the D-arginine substitution at residue 8 which may have increased its resistance towards trypsin. ${ }^{24}$ The faster degradation of large peptides in small intestinal conditions could be attributed to similar reasons, as observed in gastric fluids. Similar findings have previously been reported with salmon calcitonin and insulin, which were shown to be vulnerable to digestion in SIF, ${ }^{25-27}$ rat Gl fluids, ${ }^{28-30}$ and PIF. ${ }^{27}$ A much slower degradation of insulin was observed in another study in the presence of proteases, with complete drug loss achieved only after 1 hour. ${ }^{31}$ This highlights the significance of studying the 
stability of peptides under identical experimental conditions in biological fluids obtained from the same source, and using the same analytical techniques/instruments for analysis, to minimize the variability observed in the results obtained from different studies.

Owing to the ethical limitations on access to human Gl fluids, the need to develop a suitable invitro system that can be used for prediction of biopharmaceutical drug stability in early-stage drug development would be beneficial. The current study has highlighted the use of simulated and pig Gl fluids as an effective in-vitro tool to predict the stability of biopharmaceuticals in the human GI tract by mimicking the physiological conditions. Considering the correlation observed between the half-life of peptides in SGF and PGF compared to HGF, both models appear to effectively mimic the in-vitro stability in human gastric conditions. However, the half-life of some peptides in small intestinal fluids could not be determined due to the extremely rapid rate of degradation; hence the same correlation could not be achieved between the stability of peptides in small intestinal fluids. However, the degradation of peptides in PIF and SIF showed similar trends as that observed in HIF, highlighting their ability to be implemented as good surrogates to HIF.

\section{CONCLUSIONS}

The stability of proteins and peptides in gastrointestinal fluids is an inherent problem associated with the oral delivery of these biopharmaceuticals. In order to ascertain whether differences existed in terms of peptide stability relating to factors such as molecular weight and size as well as regional exposure to gut fluids, we investigated the stability of 17 peptide drugs in human, pig and simulated fluids. Peptide stability was shown to vary widely depending on the amino acid sequence and higher structures. Cyclisation due to disulfide bond linkages resulting in high rigidity and low flexibility appeared to provide resistance against enzymatic cleavage of susceptible peptide bonds. Larger peptides, however, were more vulnerable to enzymatic cleavage due to the higher number of enzyme susceptible peptide bonds, and high structural flexibility. SGF and PGF appeared to be reasonably good models for predicting peptide stability in the human stomach, as they both demonstrated good correlation in terms of peptide stability to HGF. Despite similarities in the trend in peptide degradation in both PIF and SIF compared to HIF, a correlation of the half-lives could not be obtained due to the rapid rate of degradation in this segment of the gut. The overall outcome of the work has made it possible to identify those features in the structure of the molecules that influence gastric and intestinal stability, allow for better selection of peptide candidates for oral delivery, and determine suitable formulation strategies for those molecules with inherent stability issues.

\section{ACKNOWLEDGEMENT}

The authors wish to acknowledge the efforts of Bertil Abrahamsson and Anders Borde from AstraZeneca, Sweden in supplying the human gastric and small intestinal fluids. 


\section{REFERENCES}

(1) Nasrollahi, S. A.; Taghibiglou, C.; Azizi, E.; Farboud, E. S. Cell-penetrating peptides as a novel transdermal drug delivery system. Chem Biol Drug Des 2012, 80, (5), 639-46.

(2) Balducci, A. G.; Ferraro, L.; Bortolotti, F.; Nastruzzi, C.; Colombo, P.; Sonvico, F.; Russo, P.; Colombo, G. Antidiuretic effect of desmopressin chimera agglomerates by nasal administration in rats. Int $J$ Pharm 2013, 440, (2), 154-60.

(3) Tian, W.; Hu, Q.; Xu, Y. Effect of soybean-lecithin as an enhancer of buccal mucosa absorption of insulin. Biomed Mater Eng 2012, 22, (1-3), 171-8.

(4) Murata, M.; Yonamine, T.; Tanaka, S.; Tahara, K.; Tozuka, Y.; Takeuchi, H. Surface modification of liposomes using polymer-wheat germ agglutinin conjugates to improve the absorption of peptide drugs by pulmonary administration. J Pharm Sci 2013.

(5) Fjellestad-Paulsen, A.; Hoglund, P.; Lundin, S.; Paulsen, O. Pharmacokinetics of 1deamino-8-D-arginine vasopressin after various routes of administration in healthy volunteers. Clin Endocrinol (Oxf) 1993, 38, (2), 177-82.

(6) Craik, D. J.; Fairlie, D. P.; Liras, S.; Price, D. The future of peptide-based drugs. Chem Biol Drug Des 2013, 81, (1), 136-47.

(7) Busby, R. W.; Kessler, M. M.; Bartolini, W. P.; Bryant, A. P.; Hannig, G.; Higgins, C. S.; Solinga, R. M.; Tobin, J. V.; Wakefield, J. D.; Kurtz, C. B.; Currie, M. G. Pharmacologic properties, metabolism, and disposition of linaclotide, a novel therapeutic peptide approved for the treatment of irritable bowel syndrome with constipation and chronic idiopathic constipation. $J$ Pharmacol Exp Ther 2013, 344, (1), 196-206.

(8) Smart, A. L.; Gaisford, S.; Basit, A. W. Oral peptide and protein delivery: intestinal obstacles and commercial prospects. Expert Opin Drug Deliv 2014, 1-13.

(9) Mahato, R. I.; Narang, A. S.; Thoma, L.; Miller, D. D. Emerging trends in oral delivery of peptide and protein drugs. Crit Rev Ther Drug Carrier Syst 2003, 20, (2-3), 153-214.

(10) Hamuro, Y.; Coales, S. J.; Molnar, K. S.; Tuske, S. J.; Morrow, J. A. Specificity of immobilized porcine pepsin in H/D exchange compatible conditions. Rapid Commun Mass Spectrom 2008, 22, (7), 1041-6.

(11) Matsui, K.; Kimura, T.; Ota, K.; litake, K.; Shoji, M.; Inoue, M.; Yoshinaga, K. Resistance of 1-deamino-[8-D-arginine]-vasopressin to in vitro degradation as compared with arginine vasopressin. Endocrinol Jpn 1985, 32, (4), 547-57.

(12) Fjellestad-Paulsen, A.; Söderberg-Ahlm, C.; Lundin, S. Metabolism of vasopressin, oxytocin, and their analogues in the human gastrointestinal tract. Peptides 1995, 16, (6), 11417.

(13) Shen, W. H.; Xu, R. J. Gastrointestinal stability and absorption of insulin in suckling pigs. Comp Biochem Physiol A Mol Integr Physiol 2000, 125, (3), 389-401.

(14) Wintersteiner, O.; Abramson, A. H. The Isoelectric Point of Insulin. Electrical properties of adsorbed and cyrstalline insulin. The Journal of Biological Chemistry 1932, 741-753.

(15) Borde, A. S.; Karlsson, E. M.; Andersson, K.; Bjorhall, K.; Lennernas, H.; Abrahamsson, B. Assessment of enzymatic prodrug stability in human, dog and simulated intestinal fluids. Eur J Pharm Biopharm 2012, 80, (3), 630-7.

(16) Lindahl, A.; Ungell, A. L.; Knutson, L.; Lennernäs, H. Characterization of fluids from the stomach and proximal jejunum in men and women. Pharm Res 1997, 14, (4), 497-502.

(17) Inouye, K.; Fruton, J. S. Studies on the Specificity of Pepsin. Biochemistry 1967, 6, (6), 1765-1777.

(18) Knowles, J. R. Enzyme Specificity : a-Chymotrypsin. Journal of Theoritical Biology $1965,9,213-228$. 
(19) Miller, S. M.; Simon, R. J.; Ng, S.; Zuckermann, R. N.; Kerr, J. M.; Moos, W. H. Comparison of the Proteolytic Susceptibilities of Homologous L-Amino Acid, D-Amino Acid, and N-Substituted Clycine Peptide and Peptoid Oligomers. Drug Development Research 1995, 35, 20-32.

(20) Soderhall, J. A.; Polymeropoulos, E. E.; Paulini, K.; Gunther, E.; Kuhne, R. Antagonist and agonist binding models of the human gonadotropin-releasing hormone receptor. Biochemical and Biophysical Research Communications 2005, 333, (2), 568-582.

(21) Kafka, A. P.; McLeod, B. J.; Rades, T.; McDowell, A. Release and bioactivity of PACA nanoparticles containing D-Lys(6)-GnRH for brushtail possum fertility control. $J$ Control Release 2011, 149, (3), 307-13.

(22) Fredholt, K.; Ostergaard, J.; Savolainen, J.; Friis, G. J. alpha-Chymotrypsin-catalyzed degradation of desmopressin (dDAVP): influence of $\mathrm{pH}$, concentration and various cyclodextrins. Int J Pharm 1999, 178, (2), 223-9.

(23) Law, S. L.; Huang, K. J.; Chou, V. H. Stability of desmopressin loaded in liposomes. J Liposome Res 2003, 13, (3-4), 269-77.

(24) Woodley, J. F. Enzymatic barriers for GI peptide and protein delivery. Crit Rev Ther Drug Carrier Syst 1994, 11, (2-3), 61-95.

(25) Chen, C.; Fan, T.; Jin, Y.; Zhou, Z.; Yang, Y.; Zhu, X.; Zhang, Z. R.; Zhang, Q.; Huang, $Y$. Orally delivered salmon calcitonin-loaded solid lipid nanoparticles prepared by micelledouble emulsion method via the combined use of different solid lipids. Nanomedicine (Lond) 2012.

(26) Ryan, S. M.; Frias, J. M.; Wang, X.; Sayers, C. T.; Haddleton, D. M.; Brayden, D. J. PK/PD modelling of comb-shaped PEGylated salmon calcitonin conjugates of differing molecular weights. J Control Release 2011, 149, (2), 126-32.

(27) Werle, M.; Kolmar, H.; Albrecht, R.; Bernkop-Schnurch, A. Characterisation of the barrier caused by luminally secreted gastro-intestinal proteolytic enzymes for two novel cystineknot microproteins. Amino Acids 2008, 35, (1), 195-200.

(28) Cheng, W.; Satyanarayanajois, S.; Lim, L. Y. Aqueous-soluble, non-reversible lipid conjugate of salmon calcitonin: synthesis, characterization and in vivo activity. Pharm Res 2007, 24, (1), 99-110.

(29) Tozaki, H.; Odoriba, T.; Iseki, T.; Taniguchi, T.; Fujita, T.; Murakami, M.; Muranishi, S.; Yamamoto, A. Use of protease inhibitors to improve calcitonin absorption from the small and large intestine in rats. J Pharm Pharmacol 1998, 50, (8), 913-20.

(30) Mansoor, S.; Youn, Y. S.; Lee, K. C. Oral delivery of mono-PEGylated SCT (Lys18) in rats: regional difference in stability and hypocalcemic effect. Pharm Dev Technol 2005, 10, (3), 389-96.

(31) Schilling, R. J.; Mitra, A. K. Degradation of insulin by trypsin and alpha-chymotrypsin. Pharm Res 1991, 8, (6), 721-7. 